\title{
Fecal carriage of extended-spectrum $\beta$-lactamase- and AmpC- producing Escherichia coli among healthcare workers
}

\author{
Rasha H Bassyouni, Sylvana Nady Gaber, Ahmed Ashraf Wegdan \\ Medical Microbiology and Immunology Department, Faculty of Medicine, Fayoum University, Fayoum, Egypt
}

\begin{abstract}
Introduction: Commensal E. coli can be considered a reservoir of genes coding for antibiotic resistance that may be transmitted in hospitals by healthcare workers (HCWs). This study aimed to determine the fecal carriage rate of extended-spectrum $\beta$-lactamase (ESBL)-producing E. coli among HCWs.

Methodology: Stool samples were collected from 200 HCWs. Phenotypic screening for ESBL and AmpC $\beta$-lactamases was performed using disk diffusion and minimum inhibitory concentration methods followed by the combined disks test and double synergy differential test for confirmation. Multiplex polymerase chain reaction (PCR) was used to detect $b l a_{\mathrm{SHV}}, b l a_{\mathrm{TEM}}, b l a_{\mathrm{CTX}-\mathrm{M}}$, and CIT groups for AmpC genes.

Results: Of $200 \mathrm{E}$. coli isolates, 100\% were susceptible to imipenem, and 59 (29.5\%) were resistant to one or more third-generation cephalosporins. By molecular analysis, 21\% (42/200) were colonized by ESBL-producing E. coli, and 3\% (6/200) were colonized by AmpCproducing E. coli. The $b l a_{\mathrm{SHV}}$ gene was the predominant ESBL gene, detected in $81.8 \%$ of the resistant E. coli isolates.

Conclusions: These findings highlight the increase in fecal carriage of $E$. coli carrying ESBL and AmpC genes among HCWs, which may be one of the causes of the spread of ESBL-producing bacteria in hospitals and requires sound infection control measures. This is the first study of the fecal carriage rate of $E$. coli carrying AmpC genes in HCWs.
\end{abstract}

Key words: E. coli; ESBL; AmpC; HCWs.

J Infect Dev Ctries 2015; 9(3):304-308. doi:10.3855/jidc.5633

(Received 20 July 2014 - Accepted 23 November 2014)

Copyright $(\odot) 2015$ Bassyouni et al. This is an open-access article distributed under the Creative Commons Attribution License, which permits unrestricted use, distribution, and reproduction in any medium, provided the original work is properly cited.

\section{Introduction}

E. coli-producing extended-spectrum $\beta$-lactamases (ESBLs) are considered one of the most multidrug resistant (MDR) pathogens in hospitals. Infections caused by ESBL-producing organisms have resulted in reduced rates of clinical and microbiological responses, longer hospital stays, and great hospital expenses. Gastrointestinal colonization is one of the most frequent reservoirs of infection [1].

The importance of detecting carriers of antimicrobial-resistant bacteria in patients and healthy people has recently increased. The increase in the proportion of carriers heightens the risk that other individuals will become carriers as a consequence of human-to-human transmission of resistant bacteria. Also, environmental enriching by the resistance gene pool may facilitate the acquisition of resistance mechanisms by susceptible bacteria [2].

Several studies have evaluated fecal carriage of ESBL-producing isolates from the stools of healthy individuals in community settings [3-5], but aside from one recent study [6], they did not specifically investigate ESBLs in healthcare workers (HCWs).
E. coli that produces both ESBLs and AmpC has been increasingly reported worldwide. The AmpCproducing organisms can act as a hidden reservoir for ESBLs; the high-level expression of the AmpC $\beta$ lactamases may mask the recognition of the ESBLs [7].

The present study aimed to determine the prevalence of fecal carriage of ESBL-producing $E$. coli among HCWs by conventional microbiological methods and on a molecular basis, and also to determine the prevalence of fecal carriage of AmpC $\beta$ lactamases and combined ESBLs including AmpC $\beta$ lactamases.

\section{Methodology}

The present study was conducted at Fayoum University Hospital. Fecal samples were collected from $200 \mathrm{HCWs}$ accepted to participate in the study who had not been recently hospitalized and had no recent exposure to antibiotics ( $\geq 3$ months); 46 (23\%) isolates were from internal medicine and intensive care units (ICUs), 40 (20\%) were from operating theaters, $39(19.5 \%)$ were from surgical wards, 27 
(13.5\%) were from outpatients clinics, $22(11 \%)$ were from pediatric wards, $17(8.5 \%)$ were from obstetrics, and $9(4.5 \%)$ isolates were from laboratory staff. The study was approved by Fayoum University's ethics committee.

\section{Bacterial isolates}

Fresh stools samples were collected (between January 2013 and July 2013) and transported to the Department of Medical Microbiology and Immunology. The samples were cultured on MacConkey agar plates (Oxoid, Basingstoke, UK) and then incubated for $18-20$ hours at $37^{\circ} \mathrm{C}$. E. coli was isolated and identified according to conventional microbiological methods [8].

Phenotypic screening for ESBL- and AmpC $\beta$ lactamase-producing strains

$E$. coli isolates were tested for $\beta$-lactamase production using the Kirby-Bauer disk diffusion method. The antibiotics used in the study included a second-generation cephalosporin (cefoxitin, $30 \mu \mathrm{g}$ ); third-generation cephalosporins (ceftazidime, $30 \mu \mathrm{g}$ and cefotaxime, $30 \mu \mathrm{g}$ ); a fourth-generation cephalosporin (cefepime, $30 \mu \mathrm{g}$ ); monobactam (aztreonam, $30 \mu \mathrm{g}$ ); $\beta$-lactam- $\beta$-lactmase inhibitor (amoxicillin-clavulanic acid, 20/10 $\mu \mathrm{g}$ ); carbapenem (imipenem, $10 \mu \mathrm{g}$ ); a quinolone (ciprofloxacin, $5 \mathrm{mg}$ ); and an aminoglycoside (amikacin, $30 \mu \mathrm{g}$ ) (Oxoid). Amoxicillin-clavulanic acid was placed in the center and on either side of the disk, ceftazidime and cefotaxime were used for detection of any synergy, cefoxitin was used for AmpC $\beta$-lactamase screening, and imipenem was also used to detect any carbapenem-resistant isolates $[9,10]$. For quality control, E. coli ATCC 25922 was used.

Minimum inhibitory concentrations (MIC) of ceftazidime and cefotaxime at concentrations ranging from 0.025 to $500 \mu \mathrm{g} / \mathrm{mL}$ were determined by microdilution method. A MIC of the cephalosporins of $\geq 2 \mu \mathrm{g} / \mathrm{mL}$ is suggestive of ESBL production [11].

Isolates with one or more of the following criteria were considered to be potential ESBLs and were listed for confirmation of ESBL production by the combined disks method. The criteria included an inhibition zone to ceftazidime $\leq 22 \mathrm{~mm}$, cefotaxime $\leq 27 \mathrm{~mm}$, aztreonam $\leq 27 \mathrm{~mm}$, extension of the zone of inhibition of any cephalosporins towards amoxicillinclavulanic acid by the disk diffusion method, or MIC of ceftazidime or cefotaxime $\geq 2 \mu \mathrm{g} / \mathrm{mL}$ [10]. Isolates resistant to cefoxitin (inhibition zone $<18 \mathrm{~mm}$ ), in addition to being resistant to one or more of the third- generation cephalosporins and being intermediate or resistant to amoxicillin-clavulanic acid were considered as putative AmpC $\beta$-lactamase producers $[9,12]$.

Phenotypic confirmatory tests for ESBL production

The combined discs method was used; Cefotaxime $(30 \mu \mathrm{g})$ and ceftazidime $(30 \mu \mathrm{g})$ disks with or without clavulanate $(10 \mu \mathrm{g})$ were used for confirmatory phenotypic detection of the ESBL-producing strains [11].

Isolates with negative results by the combined disks method were tested using the double synergy differential test (DSDT) for detection of AmpC $\beta$ lactamases or combined ESBL and AmpC $\beta$ lactamases [12].

\section{Detection of ESBLs and plasmid AmpC genes}

Automated DNA extraction was performed with MagNA Pure-DNA Isolation and Purification Kit I using a MagNA Pure LC 2.0 Instrument (Roche Lifescience, Penzberg, Germany). Multiplex polymerase chain reaction (PCR) amplification was performed as described previously by group-specific primers to $b l a_{\mathrm{TEM}}, b l a_{\mathrm{SHV}}, b l a_{\mathrm{CTX}-\mathrm{M}}$ group 1 and CIT group for the AmpC gene [13, 14] (Table 1).

\section{Statistical analysis}

All statistical calculations were done using computer programs SPSS (Statistical Package for the Social Science) version 15 for Microsoft Windows. Data were statistically described in terms of frequencies and percentages. $\mathrm{P}$ values less than 0.05 were considered statistically significant.

\section{Results}

Antibiotic susceptibility and phenotypic screening for ESBL and AmpC $\beta$-lactamase-producing strains

All 200 isolates were susceptible to imipenem. The rates of resistance (to $\beta$-lactam antibiotics) were as follows: ceftazidime (19.5\%), cefotaxime (13.5\%), cefepime (10\%), aztronam (9\%), amoxicillinclavulanic acid (8\%), and cefoxitin (8\%). In non- $\beta$ lactamase antibiotics, the resistance rates were $2.5 \%$ to ciprofloxacin and $1.5 \%$ to amikacin. Screening tests for ESBL and AmpC production revealed that the prevalence of third-generation cephalosporin resistance among E. coli was $29.5 \%$ (59/200) (16 isolates screened positive for AmpC production). Of these, 7/59 isolates were MDR, 56/59 were resistant to ceftazidime, and 49/59 were resistant to cefotaxime. The $\mathrm{MIC}_{50}$ of cefotaxime and ceftazidime was 500 
$\mu \mathrm{g} / \mathrm{mL}$, and the $\mathrm{MIC}_{90}$ of cefotaxime and ceftazidime was $>500 \mu \mathrm{g} / \mathrm{mL}$.

\section{Phenotypic confirmatory tests for ESBL production}

Out of 59 isolates (with third-generation cephalosporin resistance), $37(62.7 \%)$ were positive for ESBLs by the combined disks method. The remaining $22(37.3 \%)$ negative isolates were examined by DSDT, which detected five isolates $(22.7 \%)$ that produced AmpC $\beta$-lactamases and four isolates $(18.2 \%)$ that produced combined ESBL and AmpC $\beta$ lactamases.

Detection of ESBL and plasmid AmpC genes

Among 59 isolates resistant to third-generation cephalosporins, 44 were positive with multiplex PCR to one or more of the tested genes. All 44 ESBL- and AmpC-producing E. coli isolates were susceptible to imipenem, and $100 \%, 52.3 \%, 43.1 \%, 41 \%, 29.5 \%$, $27.3 \%, 13.6 \%$, and $9.1 \%$ were resistant to ceftazidime, cefotaxime, amoxicillin-clavulanic acid, cefepime, cefoxitin, aztreonam, ciprofloxacin, and amikacin, respectively. The prevalence of genes encoding ESBLs and AmpC among HCWs is illustrated in Table 2, while the distribution of tested genes among the 44 resistant isolates is illustrated in Table 3.

\section{Discussion}

The evolution of antibiotic resistance is a continuous threat to human health worldwide [4]. E. coli may act as a reservoir of genes coding for antibiotic resistance and may also be responsible for a group of endogenous infections. Large unrecognized reservoirs of HCWs with ESBL- and AmpC-producing E. coli may lead to transmission of antimicrobialresistant strains in hospitals from HCWs to patients, especially if the HCWs do not adhere to infection control measures at their hospitals [7].

In the current study, we determined the prevalence of fecal carriage of ESBLs, AmpC, and combined ESBL and AmpC $\beta$-lactamases among HCWs at Fayoum University Hospital and found that the prevalence of fecal carriage of ESBL-producing $E$. coli among HCWs was $21 \%$. This result partially

Table 1. Group-specific primers used in the study

\begin{tabular}{|c|c|c|c|}
\hline $\begin{array}{l}\text { Group-specific primer } \\
\text { names }\end{array}$ & Target & Sequence $\left(5^{\prime}-3^{\prime}\right)$ & $\begin{array}{c}\text { Amplicon } \\
\text { size (bp) }\end{array}$ \\
\hline \multirow{2}{*}{ Multiplex I TEM, SHV } & TEM-like & $\begin{array}{l}\text { CATTTCCGTGTCGCCCTTATTC } \\
\text { CGTTCATCCATAGTTGCCTGAC }\end{array}$ & 800 \\
\hline & SHV-like & $\begin{array}{l}\text { AGCCGCTTGAGCAAATTAAAC } \\
\text { ATCCCGCAGATAAATCACCAC }\end{array}$ & 713 \\
\hline Multiplex II CTX-M group 1 & $\begin{array}{c}\text { CTX-M group } 1 \text { including CTX-M-1, CTX-M-3 } \\
\text { and CTX-M-15 }\end{array}$ & $\begin{array}{l}\text { TTAGGAARTGTGCCGCTGYA }^{\mathrm{b}} \\
\text { CGATATCGTTGGTGGTRCCAT }^{\mathrm{b}}\end{array}$ & 688 \\
\hline Multiplex III CIT group & $\begin{array}{l}\text { LAT-1 to LAT-3, BIL-1, CMY-2 to CMY-7, } \\
\text { CMY-12 to CMY-18, and CMY-21 to CMY-23 }\end{array}$ & $\begin{array}{l}\text { CGAAGAGGCAATGACCAGAC } \\
\text { ACGGACAGGGTTAGGATAGY }^{b}\end{array}$ & 538 \\
\hline
\end{tabular}

Table 2. Prevalence of resistant genes encoding ESBLs and AmpC among HCWs

\begin{tabular}{ccc}
\hline Test & No. of positive isolates & Percentage of positive isolates \\
\hline Disk diffusion method & $59 / 200$ & $29.5 \%$ \\
PCR & $44 / 200$ & $22 \%$ \\
ESBLs (by PCR) & $42 / 200$ & $21 \%$ \\
AmpC (by PCR) & $6 / 200$ & $3 \%$ \\
\hline
\end{tabular}

Table 3. Distribution of tested genes among 44 resistant isolates

\begin{tabular}{ccc}
\hline Gene & No. of positive isolates & Percentage of positive isolates \\
\hline bla $a_{\mathrm{SHV}}$ & 36 & $81.8 \%$ \\
bla $_{\mathrm{TEM}}$ & 7 & $15.9 \%$ \\
bla $_{\mathrm{CTX}-\mathrm{M}}$ & 2 & $4.5 \%$ \\
$\mathrm{AmpC}$ (CIT group) & 6 & $13.6 \%$ \\
bla $_{\mathrm{SHV}}$ \& CIT group & 3 & $6.8 \%$ \\
bla $_{\mathrm{SHV}}$ \& bla $a_{\mathrm{CTX}-\mathrm{M}}$ & 2 & $4.5 \%$ \\
bla $_{\mathrm{SHV}}$ \& bla $a_{\mathrm{TEM}}$ & 1 & $2.2 \%$ \\
bla $_{\mathrm{TEM}}$ \& CIT group & 1 & $2.2 \%$ \\
\hline
\end{tabular}


agrees with a previous study in Korea that reported $20.3 \%$ fecal carriage of ESBL-producing Enterobacteriaceae (not only E. coli) in healthy Korean individuals [5]. Much lower rates were obtained in different regions of the world: $12.3 \%$ in Saudi Arabia [15], 11\% in Egypt [4], 7.3\% in Tunisia [16], and $1.8 \%$ in Portugal [3]. All these studies investigated the prevalence of ESBL-producing Enterobacteriaceae in community settings rather than in HCWs, which may explain the lower rates. A recent study conducted in multiple rehabilitation centers examined colonization with ESBL-producing Enterobacteriaceae in healthcare personnel by rectal swabs and found that the prevalence was $3.5 \%$ among the isolated E. coli [6]. These results are still lower than ours. This may reflect non-adherence of HCWs to hand hygiene in our region. It could also be due to the fact that we collected stool samples from HCWs serving different hospital wards, not only rehabilitation wards. It should be noted that the percentage of resistant organisms isolated from inpatient wards is usually higher than that from outpatient areas [17].

In the current study, the prevalence of fecal carriage of AmpC genes among HCWs was 3\%. To our knowledge, this is the first study investigating the prevalence of AmpC-producing E. coli isolated from stool samples among HCWs. These results are similar to those obtained from patients in other works; Naseer et al. reported a prevalence of $3.7 \%$ of AmpC among outpatients in Norway [18], and Li et al. reported a prevalence of $1.9 \%$ [19]. These findings are nearly similar to those reported in the Czech Republic and Denmark (rates were $1.1 \%$ and $2.4 \%$, respectively) [20, 21].

In our study, the distribution of genes encoding ESBLs among 44 isolates was: $36(81.8 \%)$ isolates with $b a_{\mathrm{SHV}}, 7(15.9 \%)$ with $b l a_{\mathrm{TEM}}$, and $2(4.5 \%)$ with $b l a_{\mathrm{CTX}-\mathrm{M}}$. It appears that $b l a_{\mathrm{SHV}}$ is the predominant ESBL gene among the E. coli-resistant strains in HCWs. This is in agreement with another Egyptian study, which found that the main type of ESBL gene isolated from patients in the ICUs at Assiut University Hospitals was bla $_{\text {SHV }}$ [22].

Our results disagree with many studies all over the world that reported $b l a_{\text {СтХ-M }}$ was the predominant gene among ESBL-producing E. coli isolated from fecal samples of healthy subjects [4, 23, 24], which may be explained by the variability in resistance patterns and encoding genes according to different geographic regions.

\section{Conclusions}

In conclusion, an alarming high rate of fecal carriage of ESBL-producing E. coli among HCWs has been detected, with $b l a_{\mathrm{SHV}}$ being the most predominant gene. These results emphasize the need for continuous surveillance in hospitals for both patients and HCWs to detect resistant strains by implementing strict guidelines for antibiotic therapy and infection control measures to reduce the increasing burden of antibiotic resistance and to prevent its spread.

\section{References}

1. Yano H, Uemura M, Endo S, Kanamori H, Inomata S, Kakuta R, Ichimura S, Ogawa M, Shimojima M, Ishibashi N, Aoyagi T, Hatta M, Yamada M, Tokuda K, Kunishima H, Kitagawa M, Hirakata Y, Kaku M (2013) Molecular characteristics of extended-spectrum $\beta$-lactamases in clinical isolates from $E$. coli at a Japanese Tertiary Hospital. PLoS One 8: e64359.

2. Valverde A, Coque T, Sánchez-Moreno M, Rollán A, Baquero F, Cantón R (2004) Dramatic increase in prevalence of fecal carriage of extended-spectrum $\beta$-lactamase-producing Enterobacteriaceae during non outbreak situations in Spain. J Clin. Microbiol 42: 4769-4775.

3. Machado E, Coque T, Cantón R, Sousa JC, Peixe L (2013) Commensal Enterobacteriaceae as reservoirs of ESBL, integrons, and sul genes in Portugal. Front Microbiol 4: 1-7. doi: 10.3389/fmicb.2013.00080.

4. Lonchel C, Meex C, Gangoué-Piéboji J, Boreux R, Assoumou MO, Melin P, De Mol P (2012) Proportion of Extendedspectrum B-lactamase-producing Enterobacteriaceae in community setting in Ngaoundere, Cameroon. BMC Infect Dis 12: 1-7.

5. Ko Y, Moon H, Hur M, Park CM, Cho SE, Yun YM (2013) Fecal carriage of Extended-spectrum $\beta$-lactamase-producing Enterobacteriaceae in Korean community and hospital settings. Infection 41: 9 -13.

6. Adler A, Baraniak A, Izdebski R, Fiett J, Salvia A, Samso JV, Lawrence C, Solomon J, Paul M, Lerman Y, Schwartzberg Y, Mordechai E, Rossini A, Fierro J, Lammens C, MalhotraKumar S, Goossens H, Hryniewicz W, Brun-Buisson C, Gniadkowski M, Carmeli Y; MOSAR team (2014) A multinational study of colonization with extended spectrum $\beta$ lactamase-producing Enterobacteriaceae in healthcare personnel and family members of carrier patients hospitalized in rehabilitation centers. Clin Microbiol Infect 20: 516-523.

7. Yilmaz N, Agus N, Bozcal E, Oner O, Uzel A (2013) Detection of plasmid-mediated AmpC $\beta$-lactamase in E. coli and K.pneumoniae. Indian J Med Microbiol 31: 53-59.

8. Ewing WH (1986) The Genus Escherichia. In Edwards and Ewing, editors. Edwards and Ewing's Identification of Enterobacteriaceae, 4th ed. New York: Elsevier Science Publishing Co. 93-122.

9. Hussain M, Hasan F, Shah A, Hameed A, Jung M, Rayamajhi N, Cha SB, Yoo HS (2011) Prevalence of class A and AmpC $\beta$-lactamases in clinical E. coli isolates from Pakistan institute of medical science, Islamabad, Pakistan. Jpn J Infect Dis 64: 249-252.

10. Laghawe A, Jaitly N, Thombare V (2012) The simultaneous detection of the ESBL and the AmpC $\beta$-lactamases in gram negative bacilli. J Clin Diagn Res 6: 660-663. 
11. Clinical and Laboratory Standards Institute (CLSI) (2012) Performance standards for Antimicrobial Susceptibility Testing. 22 Informational Supplement ed. CLSI document M100-S22. Wayne, PA.

12. Tan TY, Ng LS, He J, Koh TH, Hsu LY (2009) Evaluation of screening methods to detect plasmid-mediated AmpC in $E$. coli, $K$. pneumoniae, and $P$. mirabilis. Antimicrob Agents Chemother 53: 146-149.

13. Dallenne C, Da Costa A, Decré D, Favier C, Arlet G (2010) Development of a set of multiplex PCR assays for the detection of genes encoding important $\beta$-lactamases in Enterobacteriaceae. J Antimicrob Chemother 65: 490-495.

14. Pérez-Pérez F, Hanson N (2002) Detection of plasmidmediated AmpC $\beta$-lactamase genes in clinical isolates by using multiplex PCR. J Clin Microbiol 40: 2153-2162.

15. Kader A, Kamath K (2009) Faecal carriage of ESBLproducing bacteria in the community. East Mediterr Health $\mathrm{J}$ 15: $1365-1370$.

16. Ben Sallem R, Ben Slama K, Estepa V, Jouini A, Gharsa H, Klibi N, Sáenz Y, Ruiz-Larrea F, Boudabous A, Torres C (2012) Prevalence and characterisation of ESBL-producing $E$. coli isolates in healthy volunteers in Tunisia. Eur J Clin. Microbio Infect Dis 31: 1511-1516.

17. Archibald L, Phillips L, Monnet D, Johnson JK, Harris AD, Furuno JP, Thom KA, Snyder GM, Day HR, Perencevich EN (2010) Frequent multidrug-resistant Acinetobacter baumannii contamination of gloves, gowns, and hands of healthcare workers. Infect Control Hosp Epidemiol 31: 716-721.

18. Naseer U, Haldorsen B, Simonsen G, Sundsfjord A (2010) Sporadic occurrence of CMY-2-producing multidrugresistant E. coli of ST-complexes 38 and 448, and ST131 in Norway. Clin Microbiol Infect 16: 171-178.

19. Li Y, Li Q, Du Y, Jiang X, Tang J, Wang J, Li G, Jiang Y (2008) Prevalence of plasmid-mediated AmpC $\beta$-lactamases in a Chinese university hospital from 2003 to 2005: first report of CMY-2-Type AmpC $\beta$-lactamase resistance in China. J Clin Microbiol 46: 1317-1321.
20. Husickova V, Cekanova L, Chroma M, Htoutou-Sedlakova M, Hricova K, Kolar M (2012) Carriage of ESBL- and AmpC-positive Enterobacteriaceae in the GIT of community subjects and hospitalized patients in the Czech Republic. Biomed Pap Med Fac Univ Palacky Olomouc Czech Repub 156: 348-353.

21. Hammerum A, Lester C, Jakobsen L, Porsbo LJ (2011) Faecal carriage of ESBL-producing and AmpC $\beta$-lactamaseproducing bacteria among Danish army recruits. Clin Microbial Infect 17: 566-568.

22. Ahmed S, Daef E, Badary M, Mahmoud MA, Abd-Elsayed AA (2009) Nosocomial blood stream infection in ICUs at Assiut University Hospitals (Upper Egypt) with special reference to ESBL producing organisms. BMC Res Notes 6: 76.

23. Nicolas-Chanoine M, Gruson C, Bialek-Davenet S, Bertrand X, Thomas-Jean F, Bert F, Moyat M, Meiller E, Marcon E, Danchin N, Noussair L, Moreau R, Leflon-Guibout V (2013) 10-Fold increase (2006-11) in the rate of healthy subjects with ESBL - producing E. coli faecal carriage in a Parisian checkup centre. J Antimicrob Chemother 68: 562-568.

24. Isendahl J, Turlej-Rogacka A, Manjuba C, Rodrigues A, Giske CG, Nauclér P (2012) Fecal carriage of ESBLproducing E. coli and $K$. pneumoniae in children in GuineaBissau: a hospital-based cross-sectional study. PLoS One 7: 51981.

\section{Corresponding author}

Rasha H. Bassyouni, MD

Associate Professor of Medical Microbiology and Immunology Faculty of Medicine, Fayoum University, Fayoum, Egypt

Phone: +02 01223640107

Fax: +02084636583

Email: rhb00@fayoum.edu.eg; rashabassyoni@yahoo.com

Conflict of interests: No conflict of interests is declared. 